Artikel Penelitian

\title{
Comparison of Antioxidant and Anti-Tyrosinase Activities of Pineapple (Ananas comosus) Core Extract and Luteolin Compound
}

\section{Perbandingan Aktivitas Antioksidan dan Anti-Tirosinase pada Ekstrak Bonggol Nanas (Ananas comosus) dan Senyawa Luteolin}

\author{
Dela Vrianty ${ }^{1}$, Rismawati Laila $Q^{2}$, Wahyu Widowati ${ }^{2}$, Ade Putra $\mathrm{FS}^{1}$, Dewi Fibrina ${ }^{1}$, Edy Fachrial $^{1}$, \\ I Nyoman Ehrich $L^{1}$ \\ ${ }^{1}$ Departement of Biomedical Science Faculty of Medicine University of Prima Indonesia Medan \\ ${ }^{2}$ Biomolecular dan Biomedical Research Center Aretha Medika Utama Bandung
}

\begin{abstract}
Free radicals and UV exposure can cause aging. Aging prevention needs substances that can prevent molecular oxidation reactions in cells and inhibit the activity of enzymes that trigger aging. Research on pineapple skin and flesh extract (Ananas comosus (L.) Merr.) reported the presence of luteolin compound which functions as antioxidants and antityrosinase. However, in this study, the object used was pineapple core extract (PCE), which has not been widely known for its antioxidant and antityrosinase activity. Therefore, the purpose of this study was to determine the content of phytochemical compounds, antioxidant activity, and inhibitory activity of tyrosinase enzymes by PCE and then compared with the luteolin (LT) compound test results using Fansworth method, DPPH scavenging activity assay and tyrosinase enzyme inhibition assay. Based on the study results, the phytochemical compounds contained in PCE were tannins and triterpenoids. PCE and LT produced the highest DPPH scavenging activity, which was $64.86 \%$ and $59.32 \%$ (final concentration $200 \mu \mathrm{g} / \mathrm{ml}$ and $6.25 \mu \mathrm{g} / \mathrm{ml}$ ) and the highest tyrosinase inhibition activity, which was $60.52 \%$ and $85.02 \%$ (final concentration $100 \mu \mathrm{g} / \mathrm{ml}$ ). Antioxidant activity was determined based on $1 C_{50}$ of $87.46 \mu \mathrm{g} / \mathrm{mL}$ and $4.17 \mu \mathrm{g} / \mathrm{ml}$ respectively. $I C_{50}$ tyrosinase enzyme inhibition $E B N$ and $L T$ respectively at $62.27 \mu \mathrm{g} / \mathrm{ml}$ and $5.25 \mu \mathrm{g} / \mathrm{ml}$. Antioxidant activity through DPPH free radical scavenging test and tyrosinase enzyme inhibition activity by PCE was lower than LT.
\end{abstract}

Keywords: Aging, DPPH free radical, luteolin compounds, pineapple core extract, tyrosinase enzyme

\section{ABSTRAK}

Penuaan dapat disebabkan oleh radikal bebas dan paparan sinar UV. Untuk mencegah terjadinya penuaan diperlukan bahan yang dapat bekerja mencegah reaksi oksidasi molekul di dalam sel dan menghambat aktivitas enzim pemicu penuaan. Antioksidan mampu mencegah reaksi oksidasi salah satunya dengan mekanisme pemerangkapan radikal bebas. Enzim tirosinase dapat memicu pembentukan melanin dan pigmentasi pada kulit, sehingga penghambatan aktivitasnya dapat mencegah terjadinya penuaan. Ekstrak kulit dan daging buah nanas (Ananas comosus) mengandung senyawa luteolin yang berfungsi sebagai antioksidan dan antitirosinase. Penelitian ini bertujuan untuk mengetahui kandungan senyawa fitokimia, aktivitas antioksidan, dan aktivitas penghambatan enzim tirosinase oleh ekstrak bonggol nenas (EBN) dibandingkan senyawa luteolin (LT). Metode penelitian yang digunakan yaitu uji fitokimia menggunakan metode Fansworth, uji antiokidan menggunakan metode pemerangkapan DPPH, dan uji antitirosinase dengan menguji aktivitas penghambatan enzim tirosinase. Hasil penelitian menujukkan bahwa EBN mengandung tanin dan triterpenoid. EBN dan LT memiliki aktivitas pemerangkapan DPPH tertinggi secara berurutan $64,86 \%$ dan 59,32\% (konsentrasi uji $200 \mu \mathrm{g} / \mathrm{ml} \mathrm{dan}$ $6,25 \mu \mathrm{g} / \mathrm{ml}$ ) dan aktivitas penghambatan tirosinase yang paling tinggi secara berurutan yaitu $60,52 \%$ dan $85,02 \%$ (konsentrasi uji $100 \mu \mathrm{g} / \mathrm{ml}$ ). Nilai IC $\mathrm{C}_{50}$ pemerangkapan DPPH secara berurutan EBN dan LT sebesar $87,46 \mu \mathrm{g} / \mathrm{mL}$ dan $4,17 \mu \mathrm{g} / \mathrm{mL}$. IC ${ }_{50}$ penghambatan enzim tirosinase EBN dan LT masing-masing sebesar $62,27 \mu \mathrm{g} / \mathrm{mL} \mathrm{dan} 5,25 \mu \mathrm{g} / \mathrm{mL}$. Dapat disimpulkan bahwa aktivitas antioksidan melalui uji pemerangkapan radikal bebas DPPH dan aktivitas penghambatan enzim tirosinase oleh EBN lebih rendah dibandingkan LT.

Kata Kunci: Ekstrak bonggol nanas, DPPH, luteolin, penuaan, tirosine

Korespondensi: Dela Vrianty. Departemen Sains Biomedis Fakultas Kedokteran Universitas Prima Indonesia Medan, Jl. Belanga No. 1, Medan Tel.08126500453Email:dela_vrianty@yahoo.com

DOI: http://dx.doi.org/10.21776/ub.jkb.2019.030.04.2 


\section{INTRODUCTION}

Aging is a very complex process, and several theories also explained that cellular manifestations of aging processes are also influenced by a lot of factors. Hazardous environmental stimuli such as UV and free radicals act as external skin aging factors. These factors are involved with various pathways through changes in the level of reactive oxygen species (ROS) in the body. ROS is induced by continuous UV exposure. Indonesia is a tropical country that is located in the equator and receives sun exposure throughout the season. Increased ROS and decreased antioxidants in the body cause changes in oxidant and antioxidant balance resulting in oxidative stress $(1,2)$. It will also cause cell damage and also affect skin aging.

Oxidative stress can cause a variety of chronic and degenerative diseases. Free radicals can be a cause of oxidative stress. Free radicals are very reactive and unstable because electrons do not pair with the outermost atomic orbitals. Free radicals change the aging process that is elevated in the transition of degenerative diseases. Free radicals release with molecules in cells by binding them to cause oxidation of nucleic acids, proteins, fats and even DNA (3). There are various degenerative diseases and almost all organs can be affected by degenerative diseases. Among degenerative diseases, the highest prevalence is DM (diabetes mellitus), dyslipidemia, cardiovascular disease, and cerebrovascular disease. Sources of free radicals can originate from metabolism in the human body or from external exposure (4). The body needs antioxidants as oxidation inhibitors to overcome the negative effects of free radicals. Antioxidants work by supporting reactive free radicals to make relatively stable reactive substances. Therefore, the body needs a supply of antioxidants to deal with oxidative stress (5).

The in vivo study shows that up-regulation of fibroblast elastase of the skin is regulated by the formation of oxidative stress. Radical compounds are also able to activate a series of signaling pathways that lead to apoptosis of skin fibroblasts (6). The combination of these two processes results in reduced cellular integrity of the skin. Radical inhibition is an important approach to overcome skin aging. UV exposure will also induce melanin formation in the skin layer. This formation is influenced by the enzyme tyrosinase which is responsible for the initiation of skin pigmentation. Anti-tyrosinase is needed to inhibit aging and the pigmentation process.

Antioxidants are divided into two groups based on their sources, namely, indigenous antioxidants such as SOD, glutathione peroxide and catalase, and exogenous antioxidants from outside (eg vitamins E, C, betacarotene, etc.). Exogenous antioxidants are divided into two types, namely natural antioxidants (flavonoids, vitamin E, vitamin C, and beta-carotene) as well as synthetic antioxidants such as butylated hydroxytoluene (BHT), propyl gallate (PG) and TBHQ (Di-t-butyl hydroquinone). The use of synthetic antioxidants has many risks and their use is limited. The only choice that can be used as a source of antioxidants (1.3). Many plants contain antioxidant compounds, one of which is pineapple.

Pineapple (Ananas comosus L.) is one of the leading fruit commodities in Indonesia. Besides being consumed in fresh form, pineapple can also be processed into various products such as juice, jam, syrup, and chips. Pineapple contains elements of water, sugar, organic acids, minerals, nitrogen, protein, bromelain, and all vitamins in small amounts, except vitamin D. Pineapple skin, can be processed into syrup or extracted liquid for animal feed, while the fiber in leaves can be processed into paper and textiles. Currently, the flesh of the pineapple is often used as fruit while the pineapple core is only an underutilized leftover product. Several studies have reported the presence of flavonoids and phenolic compounds that function as antioxidants in the skin and flesh of pineapple (Ananas comosus (L.) Merr.) (7). Pineapple contains nutrients that are good for human health. Pineapple fruit contains a large amount of phenolic. Although a number of flavonoids and phenolics have been identified in various pineapple cultivars, little information is available about the antioxidant activity of this phenolic. Recently it has been shown that phenolic from edible fruits is effective as an antioxidant $(8,9)$. Previous study also say that pineapple has the potential to be good source of antioxidant (10).

One of the antioxidants and anti-tyrosinase flavonoids is luteolin (LT) (11). Luteolin is a flavonoid compound known as an antioxidant. Luteolin can be found in various plants such as fruits, vegetables and medicinal plants such as cabbages, onion leaves, parsley, carrots, apple skin, broccoli, celery, peppers, chrysanthemum flowers, etc. Flavonoids are polyphenols that can counteract free radicals (12).

Studies of pineapple fruit, leaf, stem, and fruit skin have been conducted, but as far as we know there is not much information about the biological activity of pineapple core extract (13), so that research is needed to determine the content of phytochemicals, the antioxidant and antityrosinase activities in this pineapple core extract (PCE) in preventing aging compared to luteolin (LT).

\section{METHODS}

\section{Preparation PCE}

Pineapple plants used in this study were obtained from Tambaksari village, Cagak district, Subang, West Java, Indonesia. To find out the truth of pineapple botanical identity used in this study, the plant determination was carried out at Herbarium Bandung Laboratory, School of Biological Sciences, Bandung Institute of Technology. In obtaining pineapple simplicia, pineapples were sorted, washed, weighted in wet weight, dried using a food dehydrator, weighed in dry weight (crude drug), and then mashed into powder form. As much as $200 \mathrm{~g}$ of Pineapple core crude drug was then extracted using maceration techniques with $70 \%$ ethanol solvent. Every 24-hour, the filtrate was collected until the ethanol filtrate turned colorless. The filtrate was then evaporated using a rotary vacuum evaporator at a temperature of $50^{\circ} \mathrm{C}$ until obtaining an extract in a paste form, and the PCE was stored in $20^{\circ} \mathrm{C}(4,14,15)$.

\section{Phytochemical Assay}

In the phytochemical test, the modification of the Farnsworth method consisted of identification of phenols, steroids/triterpenoids, terpenoids, saponins, flavonoids, tannins, and alkaloids $(4,14,15)$. 


\section{Identification of Phenol}

Tests were carried out on a drop plate, PCE was added $\mathrm{FeCl} 3$ ( $1 \%$ in water/ethanol), if there was a change in color into green/red/purple/blue/black, it indicated a phenol $(4,14,15)$.

\section{Identification of Steroids/Triterpenoids}

PCE was stored in the drop plate, then anhydrous acetic acid was added until submerged, left for 10-15 minutes, then 1 drop of concentrated sulfuric $\left(\mathrm{H}_{2} \mathrm{SO}_{4}\right)$ was added. If there was a change in color into green/blue, it indicated the presence of steroids, the presence of red/orange deposits indicated a triterpenoid content $(4,14,15)$.

\section{Identification of Saponins}

PCE was dissolved in aquadest and shaken vigorously, and then the results were observed, saponins content was indicated by the formation of stable foam above the solution $(4,14,15)$.

\section{Identification of Tannins}

PCE was immersed in a test tube with $2 \mathrm{~N} \mathrm{HCl}$ solution then heated it over a water bath for 30 minutes and a positive reaction was characterized by the formation of orange/red on the amyl alcohol layer (top layer) $(4,14,15)$.

\section{Identification of Terpenoid}

PCE was placed on the next drop plate and added vanillin and $\mathrm{H}_{2} \mathrm{SO}_{4}$ solution, a positive reaction was characterized by a change in color that occurs to purple $(4,14,15)$.

\section{Identification of Flavonoids}

PCE was inserted in a test tube that contained $\mathrm{Mg} / \mathrm{Zn}$ granules and then $2 \mathrm{~N} \mathrm{HCl}$ solution were added, and incubated for 5-10 minutes and amyl alcohol solution was added to the filtrate. Positive reactions were characterized by the formation of orange-red color $(4,14,15)$.

\section{Identification of Alkaloids}

As much as $10 \%$ ammonia solution was added to PCE, then extraction was performed with chloroform and formed 2 layers, the bottom layer was transferred to a new test tube and added $\mathrm{HCL} 2 \mathrm{~N}$, while the acid layer (top layer) was transferred to a new test tube and added dragendrof solution. A positive reaction was characterized by the formation of yellow to red brick deposits $(4,14,15)$.

\section{DPPH Scavenging Activity Assay}

As much as $200 \mu \mathrm{l}$ DPPH $0.077 \mathrm{mmol}$ (sigma 1898-66-4) in DMSO was added with $50 \mu$ l of sample (on a microplate). The mixture was incubated at room temperature for 30 minutes, and then the absorbance value was measured at a wavelength of $517 \mathrm{~nm}$ using a microplate reader. For the negative control, DPPH was used as much as $250 \mu \mathrm{l}$, while for blanks DMSO was used as much as $250(4,14,15)$.

DPPH method antioxidant activity:

$\%$ scavenging activity $=[($ Acontrol-Aextract $) /$ acontrol $x$ 100]

\section{Tyrosinase Enzyme Inhibition Assay}

The inhibition of tyrosinase enzyme activity was measured based on the method described by sigma Aldrich (16), with minor modifications $(4,14,15)$. A mixture of solutions consisting of $20 \mu \mathrm{l}$ samples $(0.78$ $50 \mu \mathrm{g} / \mathrm{ml}), 20 \mu \mathrm{l}$ tyrosinase from mushroom enzymes $(125 \mathrm{U} / \mathrm{ml}$, sigma $\mathrm{t} 3824)$, and $140 \mu \mathrm{l}$ potassium phosphate buffer (20mm, pH 6.8, merck 104873, merck 105104) was incubated at room temperature for 15 minutes. In addition, it was also prepared for controls containing only $20 \mu \mathrm{l}$ enzymes and $160 \mu \mathrm{l}$ phosphate buffers and blanks containing only $160 \mu \mathrm{l}$ phosphate buffers and $20 \mu \mathrm{l}$ samples. Furthermore, a mixture of $20 \mu \mathrm{l}$ of the L-DOPA substrate $(1.5 \mathrm{mM}$, Sigma D9628) was added and incubated again at room temperature for 10 minutes. The absorbance was measured using a wavelength of 470nm.

The percentage of inhibitory activity was calculated using the formula:

$\%$ inhibition activity $=[($ Acontrol-Aextract $) /$ Acontrol $\times 100]$

\section{RESULT}

\section{Phytochemical Assay}

The Phytochemical tests were carried out to determine the class of chemical compounds contained in PCE by using color reagent and by observing the color changes. Phytochemical tests were carried out qualitatively using Farnsworth modification including the levels of phenol, flavonides, saponins, triterpenoids, steroids, terpenoids, tannins, and alkaloids $(4,14,15)$. To provide an overview of the compound classes contained in PCE. The results of the phytochemical test on PCE can be seen in Table 1.

Table 1. Phytochemical of PCE

\begin{tabular}{clr}
\hline No & Phytochemical test & Result \\
\hline 1. & Flavonoids & $(-)$ \\
2. & Saponins & $(-)$ \\
3. & Phenol & $(-)$ \\
4. & Tannins & $(+)$ \\
5. & Steroids/ Triterpenoids & $(-/+)$ \\
6. & Terpenoid & $(-)$ \\
7. & Alkaloids & $(-)$ \\
\hline
\end{tabular}

\section{DPPH Scavenging Activity Assay}

Based on the results, the percentage of DPPH scavenging activities by PCE and LT can be seen in Table 2 and Figure 1. The DPPH scavenging activity test data were analyzed using the SPSS program with one-way ANOVA test, followed by Post Hoc Test using the Tukey HSD test with a confidence level of $95 \%(\alpha=0.05)$. As seen in Figure 1 , the DPPH scavenging activity increased with increasing concentrations of PCE and LT used.

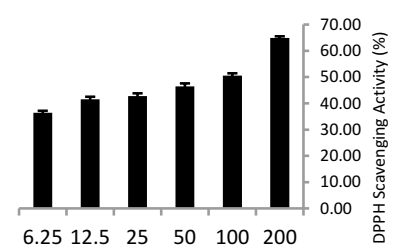

Concentration of PCE (ug/ml)

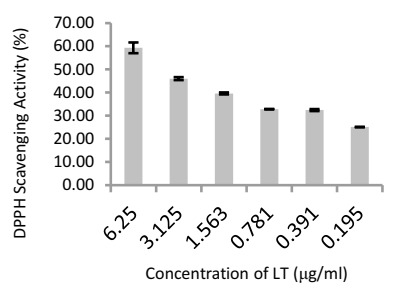

Figure 1. DPPH scavenging activity of PCE and LT 
At the highest concentration, PCE $(200 \mu \mathrm{g} / \mathrm{ml})$ and LT $(6.25 \mu \mathrm{g} / \mathrm{ml})$ produced the highest DPPH scavenging activity, which were $64.86 \pm 0.67 \%$ and $59.32 \pm 2.32 \%$, respectively (Table 2 ).

Table 2. Effect various concentrations level of PCE and LT toward DPPH scavenging activity

\begin{tabular}{lccc}
\hline $\begin{array}{c}\text { Conc. } \\
(\mu \mathrm{g} / \mathrm{ml})\end{array}$ & $\begin{array}{c}\text { DPPH Scavenging } \\
\text { Actvity of PCE }(\%)\end{array}$ & $\begin{array}{c}\text { Conc. } \\
(\mu \mathrm{g} / \mathrm{ml})\end{array}$ & $\begin{array}{c}\text { DPPH Scavenging Activity } \\
\text { of LT (\%) }\end{array}$ \\
\hline 200 & $64.86 \pm 0.67^{\mathrm{e}}$ & 6.25 & $59.32 \pm 2.32^{\mathrm{e}}$ \\
100 & $50.59 \pm 0.86^{\mathrm{d}}$ & 3.125 & $46.03 \pm 0.64^{\mathrm{d}}$ \\
50 & $46.44 \pm 1.16^{\mathrm{c}}$ & 1.563 & $39.62 \pm 0.43^{\mathrm{c}}$ \\
25 & $42.77 \pm 1.04^{\mathrm{b}}$ & 0.781 & $32.85 \pm 0.02^{\mathrm{b}}$ \\
12.5 & $41.57 \pm 0.94^{\mathrm{b}}$ & 0.391 & $32.44 \pm 0.44^{\mathrm{b}}$ \\
6.25 & $36.41 \pm 0.76^{\mathrm{a}}$ & 0.195 & $25.11 \pm 0.01^{\mathrm{a}}$ \\
\hline
\end{tabular}

Note: Data are presented in the mean \pm standard deviation. The difference in letters in the same column shows significance at $p<0.05$ (Tukey HSD post hoc test)

The results of the DPPH activity test were followed by a linear regression equation analysis test to determine the Inhibition Concentration 50 value $\left(\mathrm{IC}_{50}\right)$. The $\mathrm{IC}_{50}$ value was the antioxidant concentration needed to scavenge $50 \%$ of DPPH free radicals $(4,14,15)$. DPPH free radical scavenging by PCE and LT can be seen in Table 3. DPPH free radical scavenging by PCE and LT can be seen in Table 3. The IC ${ }_{50}$ value of PCE was higher than LT, which was $87.46 \pm 3.69$ $\mu \mathrm{g} / \mathrm{ml}$ (PCE) and $4.17 \pm 0.20 \mu \mathrm{g} / \mathrm{ml}$ (LT). Therefore, the antioxidant activity of PCE is lower than LT.

Table 3. The IC $C_{50}$ values of DPPH scavenging activity by PCE and LT

\begin{tabular}{lcccrc}
\hline Sample & Replication & Equation & $\mathbf{R 2}$ & $\begin{array}{c}\text { IC50 } \\
(\mu \mathrm{g} / \mathrm{mL})\end{array}$ & $\begin{array}{c}\text { Average } \\
\text { IC50 } \\
(\mu \mathrm{g} / \mathrm{mL})\end{array}$ \\
\hline PCE & 1 & $y=0.1243 x+39.653$ & 0.96 & 83.24 & \\
& 2 & $y=0.1382 x+37.545$ & 0.98 & 90.12 & $87.46 \pm 3.69$ \\
LT & 3 & $y=0.1328 x+38.18$ & 0.96 & 89.01 & \\
& 1 & $y=5.4759 x+28.328$ & 0.96 & 3.96 & \\
& 2 & $y=5.1162 x+28.532$ & 0.96 & 4.20 & $4.17 \pm 0.20$ \\
& 3 & $y=4.7293 x+29,406$ & 0.92 & 4.35 & \\
\hline
\end{tabular}

Note: * Linear equations, coefficient of regression (R2) and IC50 of each sample were calculated

\section{Tyrosinase Enzyme Inhibition Assay}

The inhibition of PCE tyrosinase enzyme activity and compound LT was measured based on the method described by Sigma Aldrich $(16,17)$ with minor modifications $(4,14,15)$. Data from the research results on tyrosinase enzyme inhibition activity were analyzed using the SPSS program with one-way ANOVA test, followed by Post Hoc Test using the Tukey HSD test with a confidence level of $95 \%(\alpha=0.05)$. As seen in Figure 2, tyrosinase inhibition activity increased with increasing concentrations of PCE and LT used. Overall, tyrosinase enzyme inhibition activity by LT is higher than PCE. The data is presented in Table 4 and Figure 2.

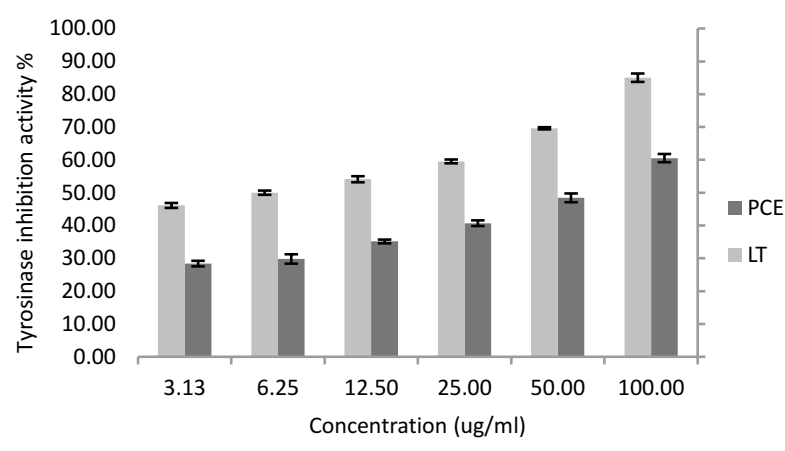

Figure 2. The comparison tyrosinase inhibition by PCE and LT

At the highest concentrations, PCE and LT produced the highest tyrosinase inhibition activity, where tyrosinase inhibition activity by LT was higher than PCE. At the highest concentration, $100 \mu \mathrm{g} / \mathrm{ml}, \mathrm{PCE}$ and LT produced the highest tyrosinase inhibitory activity, $60.52 \pm 1.25 \%$ and $85.02 \pm 1.28 \%$ (Table 4), respectively.

Table 4. Tyrosinase inhibition activity by PCE and LT

\begin{tabular}{lcc}
\hline \multirow{2}{*}{$\begin{array}{c}\text { Concentration } \\
\text { (ug/ml) }\end{array}$} & \multicolumn{2}{c}{ Tyrosinase Inhibition Activity (\%) } \\
\cline { 2 - 3 } & PCE & LT \\
\hline 100.00 & $60.52 \pm 1.25^{\mathrm{e}}$ & $85.02 \pm 1.28^{\mathrm{f}}$ \\
50.00 & $48.42 \pm 1.34^{\mathrm{d}}$ & $69.61 \pm 0.34^{\mathrm{e}}$ \\
25.00 & $40.70 \pm 0.86^{\mathrm{c}}$ & $59.52 \pm 0.58^{\mathrm{d}}$ \\
12.50 & $35.13 \pm 0.57^{\mathrm{b}}$ & $54.08 \pm 0.93^{\mathrm{c}}$ \\
6.25 & $29.80 \pm 1.43^{\mathrm{a}}$ & $49.99 \pm 0.64^{\mathrm{b}}$ \\
3.13 & $28.39 \pm 0.85^{\mathrm{a}}$ & $46.11 \pm 0.75^{\mathrm{a}}$ \\
\hline
\end{tabular}

Note: Data are presented in the mean \pm standard deviation. The difference in letters in the same column shows significance at $p<0.05$ (Tukey HSD post hoc test)

The test results of the tyrosinase enzyme inhibition activity were continued with a linear regression equation analysis test then determined the Inhibition Concentration $50\left(\mathrm{IC}_{50}\right)$ value. The $\mathrm{IC}_{50}$ value of inhibition of tyrosinase PCE and LT can be seen in Table 5. The IC ${ }_{50}$ PCE value is higher than $L T$, which is $62.27 \pm 2.34 \mu \mathrm{g} / \mathrm{ml}$ (PCE) and $5.25 \pm 1.09 \mu \mathrm{g} / \mathrm{ml}$ (LT), so the antiaging activity possessed by PCE is lower than LT.

Table 5. The IC50 value of tyrosinase inhibition by PCE and LT

\begin{tabular}{lccccc}
\hline Sample & Replication & Equation & $\mathbf{R 2}$ & $\begin{array}{c}\text { IC50 } \\
(\mu \mathrm{g} / \mathrm{mL})\end{array}$ & $\begin{array}{c}\text { Average } \\
\text { IC50 }(\mu \mathrm{g} / \mathrm{mL})\end{array}$ \\
\hline PCE & 1 & $\mathrm{y}=0.3285 x+29.589$ & 0.94 & 62.26 & \\
& 2 & $\mathrm{y}=0.3106 x+29.978$ & 0.96 & 64.61 & $62.27 \pm 2.34$ \\
& 3 & $\mathrm{y}=0.3359 x+29.921$ & 0.98 & 59.94 & \\
LT & 1 & $\mathrm{y}=0.3712 \mathrm{x}+48.463$ & 0.97 & 4.15 & \\
& 2 & $\mathrm{y}=0.3974 x+47.794$ & 0.99 & 6.32 & $5.25 \pm 1.09$ \\
& 3 & $\mathrm{y}=0.3878 x+47.96$ & 0.97 & 5.27 & \\
\hline
\end{tabular}

Note: * Linear equations, coefficient of regression (R2) and IC50 of each sample were calculated

\section{DISCUSSION}

Antioxidant and antityrosinase testing was carried out on PCE extract. The yield of pineapple core extract (PCE) was $50.04 \%$. The quality of extracts produced is usually 
inversely proportional to the amount of yield produced. The higher yield values were produced, the lower the quality was obtained. The phytochemical assay shows the chemical content in PCE, the antioxidant DPPH assay through the assay shows that PCE has strong antioxidants. In the anti-tyrosinase test, PCE showed a low inhibitory activity seen from high $\mathrm{IC}_{50}$ value.

Phytochemical tests were carried out qualitatively to analyze the presence of groups of metabolites contained in the PCE. The metabolite compounds tested included phenols, flavonoids, saponins, triterpenoids, steroids, terpenoids, tannins, alkaloids $(4,18)$. Phytochemical test results show that PCE contains only tannin and triterpenoid compounds and does not contain flavonoids, saponins, phenols, terpenoids and alkaloids.

The triterpenoid content in PCE has the potential as an antioxidant because it can donate hydrogen atoms $(\mathrm{H})$ so it can change free radicals to become non-reactive (19). The presence of triterpenoid compounds in the extract is responsible for protecting the skin due to the presence of hydroxyl substituents that is capable of inhibiting ROS, reducing metal ions, and modulating protein phosphorylation related to inhibition of enzyme activity and inhibition of lipid peroxidation $(20,21)$.

Tannin is an active compound of secondary metabolites which is known to have several properties, namely as an astringent, anti-diarrhea, anti-bacterial, and antioxidant. The more tannin content, the greater the antioxidant activity because tannins are composed of polyphenol compounds that have free radical capture activities. Tannin can also function as a biological antioxidant. Gazali et al., showed that the results of an analysis of the total phenol content had a very strong association with tyrosinase inhibitory activity. Tannin in PCE functions as an antioxidant and anti tyrosinase.

DPPH compounds (1,1-diphenyl-1-pikrilhidrazil) are nitrogen radical compounds that take the hydrogen atoms contained in a compound. The mechanism for the DPPH reaction takes places through electron transfer. DPPH free radicals can capture hydrogen atoms from extracted components which are mixed, then react to their reduced forms into non-radical DPPH (14). This process is characterized by changing color of the solution from purple to yellow $(22,23)$.

The tests on DPPH scavenging antioxidant by PCE and LT show an increase in DPPH scavenging activity along with the increasing concentrations of PCE and LT. In overall concentration, PCE has a lower scavenging activity compared to LT. At the highest concentration, PCE $(200 \mu \mathrm{g} / \mathrm{ml})$ and LT $(6.25 \mu \mathrm{g} / \mathrm{ml})$ produced the highest DPPH scavenging activity that were $64.86 \pm 0.67 \%$ and $59.32 \pm 2.32 \%$, respectively. Based on the results of calculations, the IC50 DPPH value for PCE is higher than LT, which is $87.46 \pm 3.69 \mu \mathrm{g} / \mathrm{ml}$ (PCE) and $4.17 \pm 0.20 \mu \mathrm{g} / \mathrm{ml}$ (LT). This result shows that the antioxidant activity possessed by PCE is lower than that of LT.

A compound has a strong antioxidant if the IC50 value is $<50 \mathrm{ppm}$, strong if the IC50 value is $50-100 \mathrm{ppm}$, moderate if the IC50 value is $100-150 \mathrm{ppm}$, and weak if the IC50 value is 151-200ppm (22). Based on this classification, PCE is classified as an extract which has moderate antioxidant activity while LT is a compound that has very strong antioxidant activity.
The low DPPH scavenging activity possessed by PCE can be caused by the low content of metabolites in the PCE. This is in accordance with the results of the PCE phytochemical test which only contains tannins and triterpenoids. Based on these results, the antioxidant activity of tannins and triterpenoids contained in the PCE is not higher than the antioxidant activity of LT which is an active compound of the flavonoid group. LT which has a chemical name $3^{\prime}, 4^{\prime}, 5,7$-tetrahydroxyflavone is one of the flavonoids that has an important role as an antioxidant, antidote to free radicals, anti-inflammatory, immune system modulators and anti-cancer (24).

One way to prevent or inhibit the melanin formation is by inhibiting the tyrosinase activity (25). Tyrosinase is a copper-containing enzyme catalyzing two different reactions using molecular oxygen, ortho-hydroxylation of tyrosinase (mono-phenol) at 3,4-dihydrofenylalanine or DOPA (o-phenol) which is determined as monophenolase activity, and DOPA oxidation to dopaquinone (o-quinone) is defined as diphenolase activity $(26,27)$. Dopaquinone (oquinone) is very reactive and tends to polymerize spontaneously to form brown pigment (melanin) which determine the skin color of mamals and hair. The results of the study suggest that the active compounds to inhibit tyrosinase activity are flavonoids, tannins, and saponins (28). Gazali et al., showed that the results of an analysis of the total phenol content had a very strong association with tyrosinase inhibitory activity. Total phenol content is thought to have a significant inhibitory effect on tyrosinase enzymes and prevent the risk of skin hyperpigmentation due to exposure to ultraviolet radiation from sunlight and state that phenolic compounds with hydroxyl $(-\mathrm{OH})$ groups (29) and carboxylic acids ( $\mathrm{COOH}$ ) (30) which is structurally similar to the tyrosinase substrate namely L-tyrosine or LDOPA. The compound has one or more acidic functional groups which indicate that the functional group plays an important role in binding to the active side of the tyrosinase enzyme.

Based on the results of testing for tyrosinase inhibition activity, it was found that the increase in the concentration of PCE and LT used was directly proportional to the increase in tyrosinase enzyme inhibition activity. At the highest concentration $(100 \mu \mathrm{g} / \mathrm{ml})$, tyrosinase inhibition activity by LT was higher than PCE, 60.52 $\pm 1.25 \%$ (PCE) and $85.02 \pm 1.28 \%$ (LT). Overall, tyrosinase enzyme inhibition activity by LT is higher than PCE. The data is presented in Table 4 and Figure 2.

Based on the calculated IC50 value, PCE has a higher value than LT, which means that PCE tyrosinase inhibition activity is lower than LT. The IC50 value of tyrosinase inhibition of PCE and LT can be seen in table 4. The IC50 PCE value is higher than LT, which is $62.27 \pm 2.34 \mu \mathrm{g} / \mathrm{ml}$ (PCE) and $5.25 \pm 1.09 \mu \mathrm{g} / \mathrm{ml}$ (LT), so the antiaging activity possessed by PCE is lower than LT.

An et al., stated that LT could inhibit cellular melanogenesis as effective as arbutin, one of the anti-pigmentation ingredients that are widely used in cosmetics. Luteolin flavonoids are very effective in inhibiting the oxidation of dihydroxyphenyl alanine in living cells, which is catalyzed by the enzyme tyrosinase. So, there is an anti-melanogenic effect of luteolin because luteolin has activities to inhibit the tyrosinase enzyme. 
Based on the results of the study, it is known that the phytochemical compounds contained in PCE are tannins and triterpenoids. Antioxidant activity through DPPH free radical scavenging test and tyrosinase enzyme inhibition activity by PCE is lower than LT.

\section{REFERENCES}

1. Nur S, Rumiyati R, and Lukitaningsih E. Screening of Antioxidants, Anti-Aging and Tyrosinase Inhibitory Activities of Ethanolic and Ethyl Acetate Extracts of Fruit Flesh and Fruit Peel Langsat (Lansium domesticum Corr) In Vitro. Majalah Obat Tradisional. 2017; 22(1): 63-72.

2. Widowati W, Noverina R, Ayuningtyas W, et al. Reactive Oxygen Species and Aging Mechanism. In: Wilkerson S (Ed). Reactive Oxygen Species (ROS) Mechanisms and Role in Health and Disease. New York: Nova Science Publishers; 2018: pp. 101-134.

3. Halliwell B and Gutteridge JMC. Free radicals in biology and medicine. New York: Oxford University Press; 2015.

4. Widowati W, Fauziah $\mathrm{N}$, Herdiman $\mathrm{H}$, et al. Antioxidant and Anti Aging Assays of Oryza Sativa Extracts, Vanillin and Coumaric Acid. Journal of Natural Remedies. 2016; 16(3): 88-99.

5. Rusmana D, Wahyudianingsih R, Elisabeth M, Balqis, Maesaroh, and Widowati W. Antioxidant Activity of Phyllanthus niruri Extract, Rutin and Quercetin. The Indonesian Biomedical Journal. 2017; 9(2): 84-90.

6. Tanigawa $\mathrm{T}$, Kanazawa S, Ichibori $\mathrm{R}$, et al. (+)Catechin Protects Dermal Fibroblasts Against Oxidative Stress-Induced Apoptosis. BioMed Central Complementary and Alternative Medicine. 2014; 14(1): 1-7.

7. Fidrianny I, Virna V, and Insanu M. Antioxidant Potential of Different Parts of Bogor Pineapple (Ananas comosus [L.] Merr. Var. Queen) Cultivated in West Java-Indonesia. Asian Journal of Pharmaceutical and Clinical Research. 2018; 11(1): 129-133.

8. Adhikarimayum $\mathrm{H}$, Kshetrimayum $\mathrm{G}$, and Maibam D. Evaluation of Antioxidant Properties of Phenolics Extracted from Ananas comosus $L$. Notulae Scientia Biologicae. 2010; 2(2): 68-71.

9. da Silva DIS, Nogueira GD, Duzzioni AG, and Barrozo MAS. Changes of Antioxidant Constituents in Pineapple (Ananas comosus) Residue during Drying Process. Industrial Crops and Products. 2013; 50: 557-562.

10. Hossain MA and Rahman SM. Total Phenolics, Flavonoids, and Antioxidant Activity of Tropical Fruit Pineapple. Food Research International. 2011; 44(3): 672-676.

11. An SM, Kim HJ, Kim JE, and Boo YC. Flavonoids, Taxifolin and Luteolin Attenuate Cellular Melanogenesis Despite Increasing Tyrosinase Protein Levels. Phytotherapy Research. 2008; 22(9): 1200-1207.

12. Lin $\mathrm{Y}$, Shi R, Wang $\mathrm{X}$, and Shen HM. Luteolin, a

\section{ACKNOWLEDGEMENT}

This research was supported by University of Prima Indonesia and Aretha Medika Utama. We are thankful to our colleagues who provided expertise that greatly assisted the research.

Flavonoid with Potential For Cancer Prevention And Therapy. Current Cancer Drug Targets. 2008; 8(7): 634-646.

13. Upadhyay A, Lama JP, and Tawata S. Utilization of Pineapple Waste: A Review. Journal of Food Science and Technology Nepal. 2010; 6: 10-18.

14. Widowati W, Rani AP, Hamzah RA, et al. Antioxidant and Antiaging Assays of Hibiscus Sabdariffa Extract and Its Compounds. Natural Product Sciences. 2017; 23(3): 192-200.

15. Widowati W, Janeva WB, Nadya S, et al. Antioxidant and Antiaging Activities of Jasminum Sambac Extract, and Its Compounds. Journal of Reports in Pharmaceutical Sciences. 2018; 7(3): 270-285.

16. Tu P and Tawata S. Anti-Oxidant, Anti-Aging, and Anti-Melanogenic Properties of The Essential Oils From Two Varieties of Alpinia Zerumbet. Molecules. 2015; 20(9): 16723-16740.

17. Asthana S, Zucca P, Vargiu A V, Sanjust E, Ruggerone $P$, and Rescigno A. Structure-Activity Relationship Study of Hydroxycoumarins and Mushroom Tyrosinase. Journal of Agricultural and Food Chemistry. 2015; 63(32): 7236-7244.

18. Bera TK, Chatterjee K, and Ghosh D. In-Vitro Antioxidant Properties of the Hydro-Methanol Extract of the Seeds of Swietenia Mahagoni (L.) Jaca. Biomarkers and Genomic Medicine. 2015; 7(1): 1824.

19. Kalaskar MG and Surana SJ. Free Radical Scavenging and Hepatoprotective Potential of Ficus Microcarpa L. Fil. Bark Extracts. Journal of Natural Medicines. 2011; 65(3-4): 633-640.

20. Karim AA, Azlan A, Ismail A, et al. Phenolic Composition, Antioxidant, Anti-Wrinkles and Tyrosinase Inhibitory Activities of Cocoa Pod Extract. BioMed Central Complementary and Alternative Medicine. 2014; 14(381): 1-13.

21. Pouillot A, Polla LL, Tacchini P, Neequaye A, Polla A, and Polla B. Natural Antioxidants and Their Effects on the Skin. In: Dayan $\mathrm{N}$ and Kromidas L (Eds). Formulating, Packaging, and Marketing of Natural Cosmetic Products [Internet]. Hoboken: John Wiley \& Sons, Inc.; 2011: p. 239-257.

22. Evacuasiany E, Ratnawati $\mathrm{H}$, Liana L, et al. Cytotoxic and Antioxidant Activities of Catechins in Inhibiting the Malignancy of Breast Cancer. Oxidants and Antioxidants in Medical Science. 2014; 3(2): 141-146.

23. Widowati W, Herlina $T$, Ratnawati $H$, Constantia $G$, Deva IDGS, and Maesaroh. Antioxidant Potential of Black, Green and Oolong Tea Methanol Extracts. Biology, Medicine, \& Natural Product Chemistry. 2015; 4(2): 35-39.

24. Cysilia K Hindarto, Endang Sri Lestari, Candra Irawan 
$\mathrm{HR}$, and Rochaeni H. Antioxidant Activity of Luteolin Extracted from Nutshell Waste Arachis Hypogea. International Journal of Research in Pharmacy and Pharmaceutical Sciences. 2017; 2(6): 28-30.

25. Carniol PJ, Woolery-Lloyd H, Zhao AS, and Murray K. Laser Treatment For Ethnic Skin. Facial Plastic Surgery Clinics of North America. 2010; 18(1): 105110.

26. Ebanks J, Wickett R, and Boissy R. Mechanisms Regulating Skin Pigmentation: The Rise and Fall of Complexion Coloration. International Journal of Molecular Sciences. 2009; 10(9): 4066-4087.

27. Chang TS. An Updated Review of Tyrosinase Inhibitors. International Journal of Molecular
Sciences. 2009; 10(6): 2440-2475.

28. Gazali M, Zamani NP, and Batubara I. Potensi Limbah Kulit Buah Nyirih Xylocarpus Granatum sebagai Inhibitor Tirosinase. Depik. 2014; 3(3): 187-194.

29. Park JW, Ha YM, Moon K, et al. De Novo Tyrosinase Inhibitor: 4-(6,7-Dihydro-5H-Indeno[5,6-D]Thiazol2-YI)Benzene-1,3-Diol (MHY1556). Bioorganic \& Medicinal Chemistry Letters. 2013; 23(14): 41724176.

30. Ha YM, Park YJ, Kim JA, et al. Design and Synthesis of 5-(Substituted Benzylidene) Thiazolidine-2,4-Dione Derivatives as Novel Tyrosinase Inhibitors. European Journal of Medicinal Chemistry [Internet]. 2012; 49: 245-252 